УДК 330.341 .1

DOI: https://doi.org/10.37320/2415-3583/16.7

Терлецька В.O. кандидат економічних наук Національний університет «Львівська політехніка» ORCID: https://orcid.org/0000-0002-9334-2557

\title{
ФОРМУВАННЯ УЗГОДЖЕНОЇ СИСТЕМИ ПОКАЗНИКІВ ОЦІНЮВАННЯ РОЗВИТКУ ВЕНЧУРНИХ СТРУКТУР
}

У статті досліджено поняття «розвиток венчурних структур», проаналізовано показники розвитку венчурних структур на макрорівні та мікрорівні, а також проаналізовано та сформовано підходи до оцінювання розвитку венчурних структур шляхом формування узгодженої системи показників оцінювання розвитку венчурних структур. Визначено, щзо основними показниками розвитку венчурних структур є показники фінансового стану та результатів діяльності. Запропоновано оиінювати розвиток венчурних структур за окремими одиничними показниками фінансового стану та результатами функціонування венчурних структур або за зведеними показниками, які входять до певної підгрупи чи групи показників, узагальнюючою при иьому є інтегральна оцінка узгодженості розвитку венчурної структури, щуо сприятиме отриманню адекватної оцінки збалансованості розвитку венчурних структур.

Ключові слова: розвиток, розвиток венчурних структур, підходи до оцінювання розвитку венчурних фондів, показники ефективності функціонування, показники потенціалу.

Постановка проблеми. Нестабільність розвитку національної економіки в умовах невизначеності середовища функціонування та зростаюча конкуренція призводять до виникнення різноманітних проблем. Серед найважливіших варто виділити проблему оцінювання розвитку венчурних структур. Динамічне середовище функціонування венчурних структур диктує жор- сткі умови конкуренції, вижити в яких можливо лише завдяки своєчасній та успішній реалізації програми розвитку, підгрунтям якої $\epsilon$ інноваційний характер. Тому сьогодні все більшої актуальності набувають питання розвитку венчурних структур, можливостей за мінімальних затрат, реакції на зміни зовнішнього i внутрішнього середовища функціонування, досягнення 
максимального результату, знаючи потреби ринку, маючи чіткі і досяжні цілі, ставлячи відповідні пріоритети та знаючи напрям руху, а також дієві механізми та інструменти оцінювання розвитку венчурних структур.

Аналіз останніх досліджень і публікацій. Дослідженням питань оцінювання розвитку венчурних структур займалися такі науковці, як: М.М. Бурмака [1], Т.М. Бурмака [1], В.А. Васюренко [2], В.М. Рудой [4], Р.В. Фещур [3], М.Р. Тимощук [3], І.Л. Владимирова [5], В.С. Пугачова [5], О.Ю. Загорнов [6], В.Я. Швець [10], Г.В. Соломіна [10] та ін.

Огляд наукових джерел, які розкривають підходи до розвитку венчурних структур, методів та інструментів його оцінювання дає змогу стверджувати, що проблема оцінювання розвитку венчурних структур вимагає подальшого опрацювання, а наявні розробки мають теоретично узагальнений та рекомендаційний характер, оскільки містять лише окремі аспекти розвитку та дискретні компоненти системи оцінювання розвитку. Вищесказане актуалізує дослідження, аналізування та формування узгодженої системи показників оцінювання розвитку венчурних структур.

За останні десятиліття особливої актуальності набуває проблема оцінювання розвитку. У таких умовах виникає необхідність і доцільність формування дієвих показників оцінювання розвитку венчурних структур.

Мета статті полягає у формуванні системи показників для оцінювання розвитку венчурних структур відповідно до розробленої системи оцінювання розвитку венчурних структур шляхом інтегральної оцінки узгодженості розвитку, що сприятиме отриманню адекватної оцінки збалансованості розвитку венчурних структур.

Виклад основного матеріалу. За останні десятиліття особливої актуальності набуває проблема оцінювання розвитку венчурних структур. Поняття «розвиток» $є$ надзвичайно поширеним у науковій літературі. Опрацювання наукових джерел [1-6; 10] дало можливість визначити, що у наявних джерелах основна увага приділяється питанням досягнення певних результатів діяльності венчурних структур та процесу оцінювання таких результатів. Водночас постає необхідність та доцільність формування узгодженої системи показників оцінювання розвитку венчурних структур, оскільки венчурні структури є вагомими зацікавленими особами ринкової взаємодії та акумулюють значний капітал і вливають його у перспективні галузі економіки.

Як влучно зазначає М.M. Бурмака та T.M. Бурмака $[1$, c. 7], філософія розглядає процес розвитку як особливу форму руху, що характеризується зміною кількості, структури та якості. Кількісні зміни - це збільшення чи зменшення складових частин цілого шляхом зміни їхніх числових значень. Структурні зміни - це зміни взаємовідношення складових частин, які не обов'язково супроводжуються збільшенням чи зменшенням їх кількості. Якісні зміни означають зміни закономірності кількісних та структурних змін, що мали місце раніше.

Розвиток - це необоротний, спрямований, закономірний процес зміни структури та складу, кількісних і якісних параметрів системи. Розвиток $є$ непостійним процесом, оскільки в силу певних чинників він може бути припинений.
За даними [1, с. 13], розвиток призводить не лише до поліпшення внутрішнього стану підприємства, ефективності використання його ресурсів, а й до підвищення зовнішніх переваг підприємства перед конкурентами. Оцінку внутрішніх складників найбільш повно можна відобразити через показник потенціалу, а зовнішніх - показником конкурентоспроможності, тому підвищення рівня потенціалу є внутрішнім проявом розвитку, а збільшення конкурентоспроможності зовнішнім проявом розвитку.

Кількісні, якісні, структурні зміни являють собою зміни, які сприяють підвищенню рівня потенціалу та конкурентоспроможності [1, с. 13].

Як відомо, венчурних структур є велике різноманіття. В Україні діяльність венчурних структур представлена функціонуванням венчурних інвестиційних фондів.

Венчурний інвестиційний фонд - це корпоративний або пайовий недиверсифікований інвестиційний фонд, активи якого більше ніж на 50\% складаються 3 корпоративних прав і цінних паперів, які не котируються на фондових біржах, здійснює виключно приватне розміщення емітованих ним цінних паперів і провадить досить ризиковану інвестиційну стратегію, зокрема інвестиції в інноваційні проєкти [7].

Зважаючи на вагому роль оцінювання розвитку венчурних структур та 3 урахуванням відсутності нормативно усталеної системи показників оцінювання iii стану та тенденцій розвитку, постає актуальне завдання - формування узгодженої системи показників оцінювання розвитку венчурних структур, спираючись на результати дослідження вітчизняних і зарубіжних учених.

Оскільки поняття розвитку доволі багатоаспектне та міждисциплінарне, включає широке коло різноманітних показників, як вітчизняними, так і зарубіжними авторами відповідно до власних переконань сформовано часткові показники оцінювання розвитку венчурних фондів. Досліджені напрацювання містять часто різноманітні методики, підходи та показники 3 оцінювання розвитку венчурних фондів. Окрім того, складність та багатогранність діяльності з управління активами ускладнюють процес формування узгодженої системи показників розвитку.

За даними [4], українське законодавство не передбачає встановлення окремої категорії показників, які характеризують ефективність управління активами. В окремих нормативно-правових актах є посилання на «неефективне управління активами», проте без конкретизації параметрів такої діяльності.

Варто зазначити, що, відповідно до законодавства України, великого значення набуває Рішення Національної комісії з цінних паперів та фондового ринку (НКЦПФР) «Про затвердження Положення щодо пруденційних нормативів професійної діяльності на фондовому ринку та вимог до системи управління ризиками» від 01.10.2015 № 1597 [8], що визначає основні ризики професійної діяльності на фондовому ринку для КУА, встановлює перелік, порядок розрахунку та нормативні значення пруденційних показників, які застосовуються для вимірювання та оцінювання ризиків, визначає вимоги до професійних учасників фондового ринку щодо запобігання та мінімізації впливу 
ризиків на їхню діяльність, а також установлює періодичність здійснення розрахунків пруденційних показників та подання результатів таких розрахунків, а також даних, на основі яких здійснюються розрахунки, до НКЦПФР [8].

Пруденційні нормативи - кількісні та якісні показники, встановлені НКЦПФР із метою здійснення пруденційного нагляду, обов'язкові для дотримання професійними учасниками фондового ринку [9].

Пруденційний нагляд - система нагляду, за якої головна увага органів нагляду зосереджується на регулярному проведенні оцінки загального фінансового стану, результатів діяльності та якості керівництва [9].

Відповідно до вищевказаного положення [8], основними показниками оцінки загального фінансового стану, результатів діяльності та якості керівництва $\epsilon$ розмір власних коштів, норматив достатності власних коштів, коефіцієнт покриття операційного ризику та коефіцієнт фінансової стійкості.

За даними [4], для оцінювання ефективності управління активами інституційних інвесторів «...до існуючої системи оприлюднення інформації про діяльність ICI та КУА, яка здійснює управління його активами, належать: вартість активів ICI; вартість чистих активів ICI; винагорода КУА; показники з фінансової звітності КУА та ICI; доходність ICI». Також автор для оцінювання ефективності управління активами КУА та ICI зазначає, що найбільш загальними показниками $\epsilon$ вартість активів та вартість чистих активів ICI. При цьому, щоб детальніше визначити місце ICI в економіці України та порівняти їхню діяльність із загальним станом розвитку, пропонує обчислити коефіцієнт співвідношення активів ICI до ВВП. У праці зазначено, що «...більш інформативним є показник вартості чистих активів ICI, оскільки саме він дає змогу оцінити діяльність ICI не тільки 3 позицій зростання активів, а й із погляду існуючих у інвестиційного фонду зобов'язань». Отже, за даними [4], для встановлення адекватності використовуваних в Україні методик визначення ефективності управління активами ICI насамперед потрібно детермінувати показники, які можливо використати для таких цілей відповідно до існуючої системи оприлюднення інформації про діяльність ICI та КУА, яка здійснює управління його активами: вартість активів ICI; вартість чистих активів ICI; винагорода КУА; показники з фінансової звітності КУА та ICI; доходність ICI.

Науковці І.Л. Владимирова та В.С. Пугачова [5] вважають, що для оцінювання ефективності венчурної діяльності використання венчурного капіталу під час реалізації інноваційного проєкту в будівництві «... недостатньо використовувати лише відомі фінансові показники. У даному разі необхідний комплексний підхід», і пропонують проводити аналіз ефективності венчурних інвестицій у три етапи. Перший етап передбачає аналізування показників ефективності венчурних інвестицій в інноваційні проєкти в будівництві. Другий етап передбачає оцінювання впливу чинників ризику за методами коригування норми дисконту, методом достовірних еквівалентів, аналізом чутливості критеріїв ефективності, методом сценаріїв; аналізом імовірнісних розподілів потоків платежів, дерева рішень та методом Монте-Карло (імітаційне моделювання). Третій етап передбачає оцінювання нефінансових показ- ників ефективності венчурного інвестування в інноваційні проєкти в будівництві: позначення контрольних заходів і відповідальності учасників проєкту; надійність і досвід управлінської команди проєкту; організація внутрішніх бізнес-процесів проєкту; успішність реалізації корпоративної стратегії управління проєктом; ефективність маркетингової і рекламної стратегії проєкту.

О.Ю. Загорнов [6] під час розроблення методу оцінювання ефективності венчурних інноваційних проєктів у сфері нанотехнологій пропонує використовувати інтегральний показник на основі функціональних, експлуатаційних та вартісних характеристик створюваних нанооб'єктів; появи додаткових можливостей у науковому, технологічному і виробничому розвитку суміжних галузей господарювання; капіталізації результатів реалізації інноваційних проєктів; відповідності створюваних нанотехнологій новому технологічному порядку, враховуючи критерії віднесення продукції до сфери нанотехнологій.

Світове фінансове співтовариство проводить активну роботу у сфері стандартизації й уніфікації ключових аспектів інвестиційної діяльності. 31999 р. під егідою Міжнародної ради інвестиційних асоціацій (ICIA) у Європі впроваджуються Глобальні стандарти інвестиційної діяльності (Global Investment Performance Standards, GIPS). За даними [10], у 2007 p. Україну обрано 27-м членом Регіонального комітету країн Європи, а Українська асоціація інвестиційного бізнесу (УАІБ) упроваджує GIPS - це стандарти організації даних і подання звітності за підсумками інвестиційної діяльності.

Стандарти GIPS поділені на вісім розділів, які відображають основні елементи, що стосуються подання результативності інвестування: основні принципи відповідності GIPS, вихідні дані, методологія розрахунків, побудова композитів, розкриття інформації, презентація результатів і звітність, нерухомість і прямі інвестиції [11].

Методи та об'єкти оцінки за стандартами GIPS відображено в табл. 1.

Таблиця 1 - Методи та об'скти оцінки за стандартами GIPS

\begin{tabular}{|c|l|l|}
\hline № & \multicolumn{1}{|c|}{ Об’скт оцінки } & Метод оцінки \\
\hline 1 & Композит & $\begin{array}{l}\text { Ринкова } \\
\text { (справедлива) } \\
\text { вартість }\end{array}$ \\
\hline 2 & Портфель фінансових інструментів & Ринкова вартість \\
\hline 3 & $\begin{array}{l}\text { Цінні папери з фіксованим доходом } \\
\text { і будь-які інші активи, для яких } \\
\text { нараховується процентний доход }\end{array}$ & $\begin{array}{l}\text { Метод } \\
\text { нарахувань }\end{array}$ \\
\hline 4 & Дивіденди & $\begin{array}{l}\text { Справедлива } \\
\text { вартість }\end{array}$ \\
\hline 5 & Прямі приватні інвестиції & \multicolumn{2}{|c|}{} \\
\hline
\end{tabular}

Джерело: складено за даними [10; 11]

За даними [4], «...існуючі в Україні методики оцінки ефективності управління активами інституційних інвесторів не $є$ адекватними рівню розвитку цього виду фінансових послуг та не дають змоги повною мірою отримати якісні результати. Насамперед при- 
вертає увагу проблема недостатнього інформаційного забезпечення процесу визначення ефективності, своєрідна інформаційна дифузія - розпорошення необхідної інформації між різними джерелами та об'єктами. Окрім цього, немає єдиного підходу до визначення ефективності управління активами всіх видів інституційних інвесторів - ICI, НПФ та страхових компаній, що значно ускладнює процес проведення порівняльного аналізу. Відповідно, можна зробити висновок, що 3 метою вирішення зазначених проблем на часі розроблення та обгрунтування методик оцінки ефективності управління активами інституційних інвесторів в Україні...».

В.А. Васюренко [2] для оцінки економічного потенціалу підприємства пропонує використовувати такі показники: коефіцієнт фінансової автономії, коефіцієнт покриття довгострокових вкладень, рентабельність сукупного капіталу, коефіцієнт трансформації (коефіцієнт оборотності активів), коефіцієнт оборотності дебіторської заборгованості, рентабельність основного капіталу, показник фінансового ризику, продуктивність праці, коефіцієнт Бівера та коефіцієнт стійкості економічного росту.

Р.В. Фещур [3] зазначає, що рівень загального потенціалу не може оцінюватися лише за показниками локальної ефективності, оскільки їх узагальнення не відповідає суті синергічної системи та в результаті може призвести до отримання помилкової оцінки.

М.P. Тимощук та Р.В. Фещур [3] указують, що потенціал необхідно оцінювати як можливості структури щодо досягнення встановленої мети з урахуванням показників стану і динаміки внутрішніх ресурсів, продукції, нематеріальних активів та результатів операційної діяльності.

Отже, узагальнюючи підходи науковців до вказаної проблематики, для оцінювання потенціалу бізнес-структури потрібно оперувати показниками його результатів діяльності за попередні періоди.

Дослідження наукової літератури дало можливість виокремити два підходи до оцінювання розвитку венчурних структур, а саме: оцінювання на основі системи критеріїв і показників та оцінювання на базі інтегрального показника.

Оскільки виключною діяльністю венчурних ICI є інвестування в різні сфери економіки 3 метою отримання і розподілу прибутку між інвесторами [12], то розвиток венчурних структур передусім можна оцінити показниками ефективності функціонування (результатів діяльності), а саме: показниками вартості активів венчурних ICI, вартості чистих активів венчурних ICI, валового прибутку, показником операційних доходів, нерозподіленим прибутком, чистим доходом від реалізації, фінансовим результатом від операційної діяльності, винагородою КУА, дохідністю венчурних ICI тощо.

Основними показниками оцінювання фінансового стану венчурної структури є розмір власних коштів, норматив достатності власних коштів, коефіцієнт покриття операційного ризику, коефіцієнт фінансової стійкості тощо.

Ураховуючи напрацювання авторів [1-6; 10] у вказаному напрямі, варто зазначити, що розвиток венчурних структур можна оцінити не лише через показники результатів діяльності (поліпшення стану та динаміки функціонування), в які входять показники нарощення потенціалу венчурної структури та ступеня залучення інвестицій, а також показники фінансового стану. Кожний напрям передбачає формування відповідної системи показників, що в результаті дасть змогу здійснювати оцінювання розвитку венчурних структур шляхом інтегральної оцінки $(I)$.

Формування зведених показників кожної підгрупи здійснюють на підставі одиничних показників, а групи - на підставі зведених показників відповідних підгруп за такими формулами:

$$
\begin{gathered}
F_{j}=\sum_{i} \lambda_{i j} * F_{i j}, \quad A_{j}=\sum_{i} \lambda_{i j} * A_{i j}, \\
F=\sum_{j} \alpha_{j} * F_{j}, \quad A=\sum_{j} \alpha_{j} * A_{j}, \\
I=\beta_{1} * F+\beta_{2} * A,
\end{gathered}
$$

де $\lambda_{i j}-$ нормуючі коефіцієнти, $\alpha_{j}, \beta_{1}-\beta_{2}-$ коефіцієнти вагомості, $F_{i j}$ - одиничні показники фінансового стану венчурної структури; $A_{i j}$ - одиничні показники результатів функціонування венчурної структури; $F_{j}$ - зведені показники фінансового стану венчурної структури; $A_{j}-$ зведені показники результатів функціонування венчурної структури; $F-$ групові показники фінансового стану венчурної структури; $A$ - групові показники результатів функціонування венчурної структури; $I$ - інтегральна оцінка розвитку венчурної структури; $i$ - індекс одиничного показника; $j$ - індекс підгрупового показника.

Формування інтегральної оцінки узгодженості розвитку венчурних структур сприятиме отриманню адекватної оцінки збалансованості розвитку венчурних структур.

Окрім того, оскільки розвитку притаманні зміни кількісного, структурного та якісного характеру, то для його оцінювання розвитку венчурних структур на макрорівні доцільно скористатися показниками кількості КУА, КУА з ІСІ в управлінні та кількості сформованих ICI (таких, що досягли нормативу мінімального обсягу активу); ICI, що досягли нормативу мінімального обсягу активів за типами фондів; розподілу ICI за типами і видами з публічною пропозицією; частки активів в управлінні за областями України; частки усіх ICI (за кількістю) за областями України; частки венчурних ICI за областями України; динаміки показників активів ICI в управлінні, ВВП, відношення активів ICI до активів банків та відношення активів ICI до ВВП; вартості активів ICI; розподілу активів ICI за типами фондів; вартості чистих активів ICI; розподілу вартості чистих активів за типами фондів тощо.

Для розрахунку ефективності венчурних інвестицій в інноваційні проєкти використовують такі показники, як: внутрішня норма прибутковості, модифікована внутрішня норма прибутковості, чиста приведена вартість, термін окупності, дисконтований термін окупності, рентабельність продажу, середня норма рентабельності, індекс дисконтованої прибутковості. На основі розрахунку розглянутих показників роблять висновок про ефективність венчурного інвестування. При цьому необхідно спільне використання цих показників, оскільки вони дають змогу з різних боків оцінити економічну ефективність даного проєкту. 
Висновки. Аналіз вітчизняних і зарубіжних публікацій стосовно питань оцінювання розвитку венчурних структур та узагальнення результатів дали змогу виявити, що для оцінювання розвитку венчурних структур потрібен комплексний підхід, який повинен ураховувати не лише показники ефективності діяльності венчурних структур, а й показники фінансового стану. Кожний напрям передбачає формування відповідної системи показників, що в результаті дасть змогу здійснювати оцінювання розвитку венчурних структур шляхом інтегральної оцінки. У результаті формується інтегральний показник оцінювання розвитку венчурної структури.

\section{Список використаних джерел:}

1. Бурмака М.М., Бурмака Т.М. Управління розвитком підприємства на прикладі підприємств будівельної галузі) : монографія. Харків : ХНАДУ, 2011. 204 с.

2. Васюренко В.А. Оцінка економічного потенціалу підприємства. Науковий вісник Херсонського державного університету. Серія «Економічні науки». 2016. Вип. 17(1). С. 51-54. URL: http://nbuv.gov.ua/UJRN/Nvkhdu_en_2016_17\%281\%29_14 (дата звернення: 14.01.2021).

3. Управління соціально-економічним розвитком підприємств: методологія та інструментарій : монографія / Р.В. Фещур та ін. ; за наук. ред. проф. Р.В. Фещура. Львів : Раст-7, 2016. 226 с.

4. Рудой В.М. Методика оцінки ефективності управління активами інституційних інвесторів. Вісник Державної комісії з цінних паперів та фондового ринку. 2009. № 11-12. C. 17-24. URL: http://nbuv.gov.ua/UJRN/rcpu_2009_11-12_4 (дата 3вернення: 14.01.2021).

5. Владимирова І.Л., Пугачева В.С. Основные принципы комплексной оценки эффективности венчурного инвестирования в инновационные проекты в строительстве. Эффективность венчурного инвестирования в строительстве. Вестник РЭУ. 2013. № 2. C. 32-38.

6. Загоргов А.Ю. Разработка интегрального метода оценки эффективности венчурных инновационных проектов в сфере нанотехнологий : автореф. дис. ... канд. екон. наук : 08.00.05. Москва, 2010. 28 с.

7. Венчурний інвестиційний фонд. URL: https://uk.wikipedia.org/wiki/Інвестиційний_фонд (дата звернення: 14.01.2021).

8. Про затвердження Положення щодо пруденційних нормативів професійної діяльності на фондовому ринку та вимог до системи управління ризиками : Рішення Національної комісії з цінних паперів та фондового ринку від 01.10.2015 № 1597. URL: https://zakon.rada.gov.ua/laws/show/z1311-15\#Техt (дата звернення: 14.01.2021).

9. Затверджено Положення щодо пруденційних нормативів профдіяльності на фондовому ринку. Bicник MCФ3. URL: https://msfz.ligazakon.ua/ua/magazine_article/fz000829 (дата звернення: 14.01.2021).

10. Швець В.Я., Соломіна Г.В. Стандарти оцінки ефективності діяльності інститутів спільного інвестування: світовий досвід і Україна. Економіка промисловості. 2013. № 1-2. C. 201-208. URL: http://nbuv.gov.ua/UJRN/28 (дата звернення: 14.01.2021).

11. Коваленко Ю.М. Управління фінансовими активами : підручник : у 2-х ч. Ч. 2. Ірпінь : Університет ДФС України. 2019. 442 с.

12. Інститути спільного інвестування та їх класифікація. URL: http://ip-am.com.ua/ua/isi/classification (дата звернення: 14.01.2021).

\section{References:}

1. Burmaka M.M., Burmaka T.M. (2011) Upravlinnia rozvytkom pidpryiemstva na prykladi pidpryiemstv budivelnoi haluzi [Management of enterprise development on the example of construction companies]. Kharkiv: KhNADU. (in Ukrainian)

2. Vasiurenko V.A. (2016) Otsinka ekonomichnoho potentsialu pidpryiemstva [Assessment of the economic potential of the enterprise]. Naukovyi visnyk Khersonskoho derzhavnoho universytetu. Ser.: Ekonomichni nauky, vol. 17(1), pp. 51-54. Available at: http://nbuv.gov.ua/UJRN/Nvkhdu_en_2016_17\%281\%29_14 (accessed 14 January 2021).

3. Feshhur R.V. (2016) Upravlinnya socialno-ekonomichnym rozvytkom pidpryyemstv: metodologiya ta instrumentarij [Management of socio-economic development of enterprises: methodology and tools]. Lviv: Rast-7. (in Ukrainian)

4. Rudoi V.M. (2009) Metodyka otsinky efektyvnosti upravlinnia aktyvamy instytutsiinykh investoriv [Methods for assessing the effectiveness of asset management of institutional investors]. Visnyk Derzhavnoi komisii z tsinnykh paperiv ta fondovoho rynku, vol. 11-12, pp. 17-24. Available at: http://nbuv.gov.ua/UJRN/rcpu 2009_11-12_4 (accessed 14 January 2021).

5. Vladymyrova I.L., Puhachova V.S. (2013) Osnovnye printsipy kompleksnoy otsenki effektivnosti venchurnogo investirovaniya $\mathrm{v}$ innovatsionnye proekty $\mathrm{v}$ stroitel'stve. Effektivnost' venchurnogo investirovaniya $\mathrm{v}$ stroitel'stve [Basic principles of comprehensive assessment of the effectiveness of venture investment in innovative projects in construction. The effectiveness of venture capital investment in construction]. Vestnik REU, vol. 2, pp. 32-38.

6. Zahorhov A.Yu. (2010) Razrabotka integral'nogo metoda otsenki effektivnosti venchurnykh innovatsionnykh proektov v sfere nanotekhnologiy [Development of an integrated method for evaluating the effectiveness of venture innovation projects in the field of nanotechnology] ( $\mathrm{PhD}$ Thesis), Moscow.

7. Venchurnyi investytsiinyi fond [Venture investment fund]. Available at: https://uk.wikipedia.org/wiki/Інвестиційний_фонд (accessed 14 January 2021).

8. Pro zatverdzhennia Polozhennia shchodo prudentsiinykh normatyviv profesiinoi diialnosti na fondovomu rynku ta vymoh do systemy upravlinnia ryzykamy [On approval of the Regulations on prudential standards of professional activity in the stock market and requirements for the risk management system]. Decision of the National Commission on Securities and Stock Market (dated 01.10.2015 № 1597). Available at: https://zakon.rada.gov.ua/laws/show/z1311-15\#Text (accessed 14 January 2021).

9. Zatverdzheno Polozhennia shchodo prudentsiinykh normatyviv profdiialnosti na fondovomu rynku [Regulations on prudential standards of professional activity in the stock market have been approved]. Visnyk MSFZ. Available at: https://msfz.ligazakon.ua/ua/ magazine article/fz000829 (accessed 14 January 2021).

10. Shvets V.Ya., Solomina H.V. (2013) Standarty otsinky efektyvnosti diialnosti instytutiv spilnoho investuvannia: svitovyi dosvid i Ukraina [Standards for evaluating the effectiveness of mutual investment institutions: world experience and Ukraine]. Ekonomika promyslovosti, vol. 1-2, pp. 201-208. Available at:http://nbuv.gov.ua/UJRN/econpr 2013 1-2 28 (accessed 14 January 2021).

11. Kovalenko Yu.M. (2019) Upravlinnia finansovymy aktyvamy [Financial asset management]. Irpin: Universytet DFS Ukrainy. (in Ukrainian)

12. Instytuty spilnoho investuvannia ta yikh klasyfikatsiia [Mutual investment institutions and their classification]. Available at: http://ip-am.com.ua/ua/isi/classification (accessed 14 January 2021). 
Terletska Viktoria

Lviv Polytechnic National University

\section{FORMATION OF HARMONIZED SYSTEM OF THE INDICATORS FOR EVALUATION OF VENTURE STRUCTURES DEVELOPMENT}

The instability of the national economy in the conditions of uncertainty of the operating environment and increasing competition leads to various problems. Among the most important is the problem of assessing the development of venture structures. The dynamic environment of venture structures dictates tough conditions of competition, in which it is possible to survive only through the timely and successful implementation of the development program, which is based on innovation. Therefore, today the issues of development of venture structures, opportunities at minimal cost, response to changes in external and internal environment, to achieve maximum results, knowing market needs, having clear and achievable goals, setting appropriate priorities and knowing the direction of movement, as well as effective mechanisms and tools for assessing the development of venture structures. Development is an irreversible, directed, natural process of changing the structure and composition, quantitative and qualitative parameters of the system. Development is a non-permanent process, because due to certain factors it can be stopped. The article has been explored the concept of "development of venture structures", has been analyzed indicators of development of venture structures at the macro and micro levels, as well as has been analyzed and formed approaches to assessing the development of venture structures by forming a coherent system of indicators for assessing the development of venture structures. It is determined that the main indicators of the development of venture structures are indicators of financial condition and performance. It is proposed to assess the development of venture structures by individual units of financial condition and performance of venture structures or by consolidated indicators that are part of a subgroup or group of indicators. The analysis of domestic and foreign publications on the activities of venture structures, conducted by the authors, showed that its evaluation requires a comprehensive approach, which should take into account not only the performance of venture structures, but also indicators of the potential of the venture structure. As a result, an integrated indicator of assessing the development of the venture structure is formed.

Key words: development, development of venture structures, approaches to assessing the development of venture funds, performance indicators, capacity indicators.

JEL classification: O11, O17, O32 